\title{
Application of water pinch technology for water and wastewater minimization in aluminum anodizing industries
}

\author{
${ }^{1}$ *S. M. Khezri; ${ }^{1}$ F. Lotfi; ${ }^{2}$ S. Tabibian; ${ }^{1}$ Z. Erfani \\ ${ }^{1}$ Department of Environmental Engineering, Graduate School of the Environmental and Energy, Science and \\ Research Branch, Islamic Azad University, Tehran, Iran \\ ${ }^{2}$ Faculty of Agriculture, Roodehen Branch, Payame Noor University, Tehran, Iran \\ Received 20 October 2009; $\quad$ revised 26 November 2009; $\quad$ accepted 8 February 2010; avaiable online 1 March 2010
}

\begin{abstract}
This study aims to describe the application of water pinch technology in industrial water consumption management in aluminum anodizing industry. Water pinch analysis is a systematic technique for designing, optimization and retrofitting of energy, mass and water recovery networks. The selection of different operations existing in an industry has an important role in correctness of application of pinch technology. Water usages in anodizing industry are various, but researches have been shown that, it has the best efficiency on the selection of rinsing chambers to pinch technology. There are different methods in pinch technology mostly based on mass transfer of single or multiple contaminants. In this research, a new method is used to select effective contaminant to be applied to pinch analysis. This research is based on Mann and Liu's method in single contaminant. But "the guide for classification of raw water, wastewater and recycled water for industrial and recreation" is chosen to use a complex of index contaminants as a single contaminant. This method is very simple and applicable for various industrial processes. By an index contaminant like total dissolved solids, the water usage reduced about $6.7 \%$. Using pinch technology and this new approach in three rinsing chambers, water usage reduced about $14.4 \%$.
\end{abstract}

Keywords: Aluminum anodizing; Industrial water reuse; Mass transfer networks; Process integration, Water consumption minimization

\section{INTRODUCTION}

Today, lack of water for both drinking and industries purposes in the environment is a global concern. Therefore, it is highly important to protect of water sources. There are so many researches in water minimization to solve this problem in industries with different spatial approaches (Sorin et al., 1999; Schneider et al., 2000; Jezowski, 2008; Yu-Der et al., 2008). Process changes for minimizing of process water demand (Kutepov et al., 2002; Soon et al., 2002; Thokozani, 2005; Manan et al., 2006), reuse of wastewater of a process in another process (Wang and Smith 1994; Song et al., 2006; Vander Bruggen and Braeken., 2006; Wan Alwi and Manan, 2008; Abbaspour et al., 2009; Igbinosa and Okoh, 2009) and recycle of process wastewater to the same process (Dhole et al., 1996; Castro et al., 1999; Hallale et al., 2002; Alva Argaezea et al., 2007; Carlos et al., 2007; Zhaolin et al.,

ه*Corresponding Author Email: khezri_m@yahoo.com

Tel./Fax: +9821 44865058
2007) are some approaches. These are some methods in wastewater minimization. The pinch technology recently used is an efficient method for wastewater minimization, because three type of minimizing processes are included in one method (Panjeshahi et al., 2008; Shaobo et al. , 2008; Shoaib et al., 2008). Conceptually, water pinch technology is a same method for mass exchange integration involving water using operations (Alva-Argaez et al., 1999; Mubarak Ebrahm et al., 2000; Juliana et al., 2007; Kai Cao et al., 2007). However, this method does not involve some practical problems that hinder the real world implementation of mass exchange network, simply because water pinch technology represents an existing class of manufacturing operation. Water pinch analysis is a process integration tool, which was first developed for the design of heat recovery systems during the late 1970s (Linnhoff, 1970). Wang and Smith (1994) considered this technique for water using networks. 
Their approach was based on mass transfer. Dhole et al. (1996) introduced an approach slightly different to that of Wang and Smith (1994). This method was deigned to overcome the problem encountered in real life application of the Wang and Smith methodology. El-Halwagi and Manousiouthakis (1989); El-Halwagi et al. (2000); Rabie and El-Halwagi (2008) introduced the concept of synthesizing waste-inception networks and incorporated them into a mass integration framework for global allocation of pollutants. Gomes et al. (2007) presented an algorithmic procedure based on the construction of a concentration. Manan HWDO(2006) described how the water cascade analysis technique was adapted to establish the minimum water target for the Sultan Ismail Mosque in Malaysia. In this research, a new method is applied for determining index contaminant that shows the complexity of contaminant as a single contaminant. Thus, calculation results will be more correct than single contaminant. Also, Mann and Liu's method in single contaminant (Mann and Liu, 1999) is highly applicable. This method is a graphical method and uses simple mathematical calculation, but it is applicable for various industries. This research conducted in 2008-2009 at Alopan Company in Alborz Industrial Estate Ghazvin, Iran.

\section{MATERIAL AND METHODS}

Alupan Company has been established in 1974 in Alborz Industrial Estate in Ghazvin for production of profile and door/window, facades with annual production capacity of $11,000 \mathrm{MT}$ in $50,000 \mathrm{~m}^{2}$ with a production hall of $25,000 \mathrm{~m}^{2}$. As shown in Fig. 1, aluminum anodizing process consisted of fifty operations, which seven of them are rinsing processes and three operations include continues processes (numbers 4, 11, 13). Other processes supplied by Alborz industrial area water have weekly discharge.
In wastewater minimization with pinch technology there are two purposes:

- Wastewater minimization with considering single contaminant;

- Wastewater minimization with considering multiple contaminants.

Because of operational and technical limitations and lack of a comprehensive approach about multiple problems and acceptable results with reasonable little time consumption, wastewater minimization with considering the single contaminant is a primal goal throughout this study. In single contaminant problem, a contaminant with most effectiveness in process shall be selected. Unfortunately, there is no special information about contaminants level of required water in rinsing process in aluminum anodizing. In this study, "the guide for classification of raw water, wastewater and recycled water for industrial and recreation" is used like a required standard to water usage in rinsing operations in aluminum anodizing industries.

In this guide, industrial water is classified in four classes:

- First class (high sensitive)

- Second class (sensitive)

- Third class (relatively sensitive)

- Forth class (less sensitive)

Rinsing water is classified in less sensitive group. Waters in this group are usually used without treatment or with minimum treatment. The maximum level of each parameter in Table 1 is the closest level to allowable level for process in class four.

National Sanitation Foundation (NSF) are the pattern and numbering of these charts. Tables 2 and 3 indicates the numbering for each group. This research is based

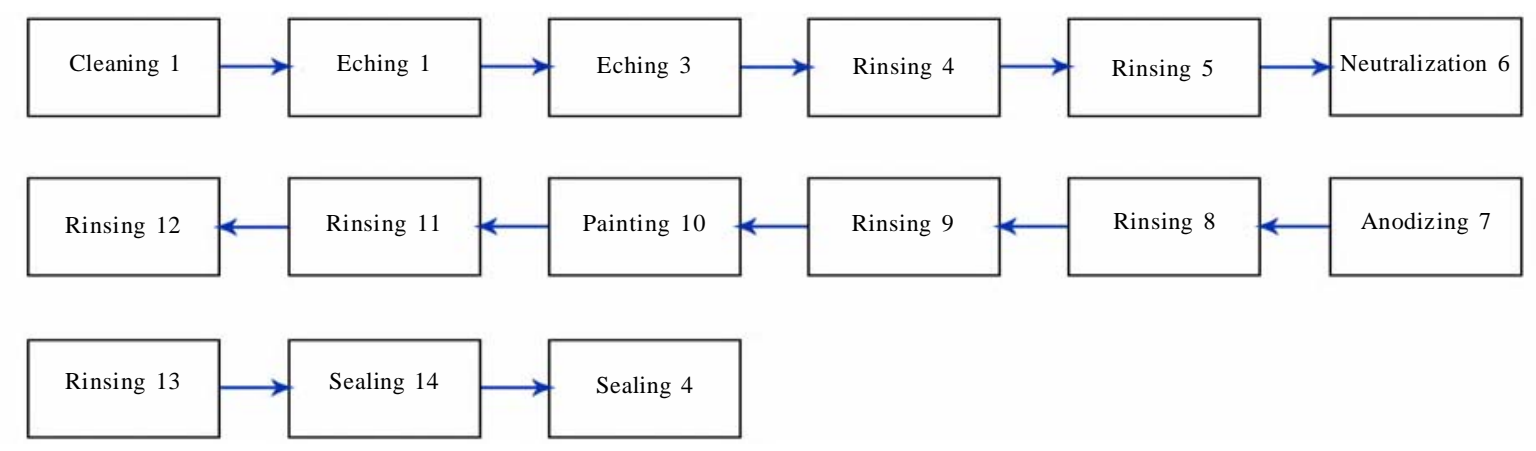

Fig. 1: Alupan aluminum anodizing flowchart 
on Mann and Liu's (1999) method in single contaminant on graphical approach. In graphical method, concentration composite curve, blok diagram and grid diagram were used. Applied method was able to present water reuse, water regeneration and water recycle and also it was able to be used in multiple contaminant water minimization system. But in the current study, it has only been used for single contaminant with a new approach using combination of contaminants as a pollution index instead of one contaminant.

\section{RESULTS AND DISCUSSION}

After sampling from all rinsing processes, all parameters in Table 1 were measured with Spectrophotometer DR Hatch 2800 apparatus according to Standard Methods. The results have been shown in Table 4. Table 5 shows the numerical limitation of various groupe of water for rinsing operations. However, in this case continues operations are considered, so others operations are to be omitted and the results of three operations are shown (numbers 4, 11 and 13) (Table 6).

\section{Determination of numerical limitation}

In determination of acceptable quality of water for rinsing operations, the following points are to be considered:

- Outlets of these operations are the sampling points, because all rinsing operations use the same source of raw water, and then the quality of waters are same.

- From the standpoint of numerical limitation (Table 5), the quality of water in inlet of operations is considered to be from group A (Table 2).

- Actually the numerical limitation (Table 2) is the water purity. Therefore, the level of waters contamination are determined from the following simple equation:

Table 1:The allowable level of parameters in class four of industrial water

\begin{tabular}{lc}
\hline Parameter & The allowable level \\
\hline Fe & $0-1$ \\
$\mathrm{Mn}$ & $0-1$ \\
$\mathrm{pH}$ & $0-500$ \\
$\mathrm{COD}$ & $0-75$ \\
Hardness & $0-500$ \\
Alkalinity & $0-500$ \\
$\mathrm{SO}_{4}$ & $0-500$ \\
Suspended Solid & $0-1000$ \\
$\mathrm{Cl}$ & $0-50$ \\
$\mathrm{Si}$ & $5-10$ \\
TDS & $0-100$ \\
\hline Source: The guide for classification of raw water, wastewater and
\end{tabular}

The level of water contamination is equal to 100 minus Numerical limitation.

\section{Determination of conditions}

Basic conditions for each operation are:

- Concentration of contaminant in inlet streams $\left(C_{i, i n}^{\text {Lim }}\right)$.

- Concentration of contaminant in outlet streams $\left(C_{i, \text { out }}^{\text {Lim }}\right)$.

- Mass load of contaminant to be transferred $\left(\Delta m_{i, t o t}\right)$.

All the above-mentioned conditions are shown in Table 7.

Minimum flow rate of fresh water without reuse Firstly, minimum fresh water flow rate needed for each operation is determined.

$f_{i, \min }=\frac{\Delta m_{i, \text { tot }}(g r / h)}{\left[C_{i, \text { out }}^{w}-C_{i, \text { in }}^{w}\right]\left(g / \mathrm{m}^{3}\right)}$

In this research, $\left(C_{i, \text { out }}^{w}\right)$ concentration of water in inlet of operations is equal to $27 \mathrm{~g} / \mathrm{m}^{3}$.

$$
f_{4, \min }=\frac{16.56(\mathrm{gr} / \mathrm{h})}{[60-27]\left(\mathrm{g} / \mathrm{m}^{3}\right)}=0.502\left(\mathrm{~m}^{3} / \mathrm{h}\right)
$$

Table 2: Numerical limitation of various groupe of water sources

\begin{tabular}{ll}
\hline Numerical limitation & Water source quality \\
\hline $100-80$ & Very good \\
$80-50$ & Good (A) \\
$50-30$ & Moderate (B) \\
$30-0$ & Bad (C) \\
\hline Source: The guide for classification of raw water, wastewater and recycled \\
\multicolumn{2}{c}{ water for industrial and recreation }
\end{tabular}

Table 3: Weight of various parameters of industrial water

\begin{tabular}{lc}
\hline Weight & Parameter \\
\hline 0.5 & $\mathrm{pH}$ \\
0.5 & $\mathrm{Mn}$ \\
0.5 & $\mathrm{Fe}$ \\
1 & $\mathrm{Cl}$ \\
1 & $\mathrm{SO}_{4}$ \\
0.5 & Suspended solids \\
1 & $\mathrm{COD}$ \\
1 & $\mathrm{Si}$ \\
2 & Hardness \\
1 & Dissolve solids \\
1 & Alkalinity \\
\hline
\end{tabular}


Application of water pinch technology for water and wastewater minimization

Table 4: The results of measuring of various parameter of rinsing operations

\begin{tabular}{|c|c|c|c|c|c|c|c|c|c|}
\hline & Unit & Water & 13 & 12 & 11 & 9 & 8 & 5 & 4 \\
\hline $\mathrm{SO}_{4}$ & $\mathrm{mg} / \mathrm{L}$ & 88 & 99 & 200 & 250 & 150 & 102 & 150 & 100 \\
\hline $\mathrm{pH}$ & - & 7 & 6 & 1 & 4.5 & 1 & 1 & 2 & 12 \\
\hline Mn & $\mathrm{mg} / \mathrm{L}$ & 0.063 & 0.072 & 0.098 & 0.103 & 0.121 & 0.11 & 0.12 & 0.5 \\
\hline $\mathrm{Fe}$ & $\mathrm{mg} / \mathrm{L}$ & 18 & 1.53 & 1.65 & 0.83 & 3.13 & 0.15 & 1.61 & 2.04 \\
\hline $\mathrm{Cl}$ & $\mathrm{mg} / \mathrm{L}$ & 2 & 0.11 & 0.1 & 0.1 & 0.2 & 0.25 & 0.2 & 0.25 \\
\hline Suspended solids & $\mathrm{mg} / \mathrm{L}$ & 1 & 3 & 30 & 200 & 50 & 90 & 120 & 140 \\
\hline COD & $\mathrm{mg} / \mathrm{L}$ & & 17 & 47 & 14 & 21 & 10 & 6 & 27 \\
\hline $\mathrm{Si}$ & $\mathrm{mg} / \mathrm{L}$ & $1 \overline{0}$ & 15 & 20 & 85 & 30 & 45 & 60 & 50 \\
\hline Hardness & $\mathrm{mg} / \mathrm{L}$ & 178 & 1068 & 409.4 & 890 & 890 & 320 & 1424 & 267 \\
\hline Dissolved solids & $\mathrm{mg} / \mathrm{L}$ & 52.5 & 2331 & 11886 & 2835 & 597.8 & 120 & 4095 & 6391 \\
\hline Turbidity & $\mathrm{mg} / \mathrm{L}$ & 0.065 & 1.53 & 2.55 & 53 & 7.81 & 13.9 & 21 & 37 \\
\hline
\end{tabular}

Table 5: Numerical limitation of various rinsing operations water

\begin{tabular}{|c|c|c|}
\hline Rinsing operations & Water quality & f $(l / s)$ \\
\hline 4 & $\mathrm{~B}$ & 0.23 \\
\hline 5 & $\mathrm{~B}$ & \\
\hline 8 & A & \\
\hline 9 & B & \\
\hline 11 & $\mathrm{~B}$ & 0.8 \\
\hline 12 & $\mathrm{~B}$ & \\
\hline 13 & $\mathrm{~B}$ & 0.95 \\
\hline Raw water & $\mathrm{A}$ & \\
\hline
\end{tabular}

Table 6: Summary of calculations of operations 4, 11 and 13

\begin{tabular}{|c|c|c|c|c|c|c|}
\hline $\begin{array}{c}\text { Number of } \\
\text { operation }\end{array}$ & Character & Amount of testing & Value (Q) & $\begin{array}{l}\text { Weight of } \\
\text { parameter }\end{array}$ & $\mathrm{Q} \times \mathrm{W}$ & $\begin{array}{l}\text { Numerical } \\
\text { limitation }\end{array}$ \\
\hline \multirow{8}{*}{4} & $\mathrm{SO}_{4}{ }^{2-}$ & 100 & 87 & 1 & 87 & \multirow{8}{*}{40} \\
\hline & $\mathrm{pH}$ & 12 & 0 & 0.5 & 0 & \\
\hline & $\mathrm{Fe}$ & 2.04 & 0 & 0.5 & 0 & \\
\hline & $\mathrm{Mn}$ & 0.5 & 45 & 0.5 & 22.5 & \\
\hline & COD & 27 & 42 & 1 & 42 & \\
\hline & TSS & 140 & 30 & 0.5 & 15 & \\
\hline & $\mathrm{Cl}$ & 0.25 & 100 & 1 & 100 & \\
\hline & $\mathrm{Si}$ & 50 & 30 & 1 & 30 & \\
\hline \multirow{13}{*}{11} & TDS & 6391 & 0 & 1 & 0 & \multirow{13}{*}{40} \\
\hline & Hardness & 267 & 50 & 2 & 100 & \\
\hline & $\mathrm{SO}_{4}=$ & 250 & 50 & 1 & 50 & \\
\hline & $\mathrm{pH}$ & 4.5 & 60 & 0.5 & 30 & \\
\hline & $\mathrm{Fe}$ & 0.83 & 38 & 0.5 & 19 & \\
\hline & $\mathrm{Mn}$ & 0.103 & 78 & 0.5 & 39 & \\
\hline & COD & 14 & 70 & 1 & 70 & \\
\hline & TSS & 200 & 25 & 0.5 & 14.5 & \\
\hline & $\mathrm{Cl}$ & 0.1 & 100 & 1 & 100 & \\
\hline & $\mathrm{Si}$ & 85 & 25 & 1 & 25 & \\
\hline & TDS & 2835 & 12 & 1 & 12 & \\
\hline & Hardness & 890 & 9 & 2 & 18 & \\
\hline & $\mathrm{SO}_{4}{ }^{=}$ & 99 & 78 & 1 & 78 & \\
\hline \multirow{9}{*}{13} & $\mathrm{pH}$ & 6 & 90 & 0.5 & 45 & \multirow{9}{*}{50} \\
\hline & $\mathrm{Fe}$ & 1.53 & 0 & 0.5 & 0 & \\
\hline & $\mathrm{Mn}$ & 0.072 & 80 & 0.5 & 40 & \\
\hline & COD & 17 & 90 & 1 & 90 & \\
\hline & TSS & 3 & 80 & 0.5 & 40 & \\
\hline & $\mathrm{Cl}$ & 0.11 & 100 & 1 & 50 & \\
\hline & $\mathrm{Si}$ & 15 & 78 & 1 & 78 & \\
\hline & TDS & 2331 & 17 & 1 & 17 & \\
\hline & Hardness & 1068 & 0 & 2 & 0 & \\
\hline
\end{tabular}


Int. J. Environ. Sci. Tech., 7 (2), 281-290, Spring 2010

Table 7: Limiting process data

\begin{tabular}{lcccccrr}
\hline Process & $\mathrm{f}\left(\mathrm{m}^{3} / \mathrm{h}\right)$ & $\begin{array}{c}\text { Inlet NSF } \\
\left(\mathrm{g} / \mathrm{m}^{3}\right)\end{array}$ & $\begin{array}{c}\text { Outlet NSF } \\
\left(\mathrm{g} / \mathrm{m}^{3}\right)\end{array}$ & $\begin{array}{c}\text { Inlet concentration } \\
(100-N S F)\left(\mathrm{g} / \mathrm{m}^{3}\right)\end{array}$ & $\begin{array}{c}\text { Outlet concentration } \\
(100-N S F)\left(\mathrm{g} / \mathrm{m}^{3}\right)\end{array}$ & $\begin{array}{c}\Delta m \\
(\mathrm{~g} / \mathrm{h})\end{array}$ & $\begin{array}{c}\text { Cumulative } \\
\mathrm{Mass} \mathrm{load}(\mathrm{g} / \mathrm{h})\end{array}$ \\
\hline 13 & 3.42 & 70 & 50 & 30 & 50 & 68.4 & 68.4 \\
11 & 2.88 & 70 & 40 & 30 & 60 & 84.4 \\
4 & 0.828 & 60 & 40 & 40 & 60 & 152.8 \\
\hline
\end{tabular}

Table 8: Minimum fresh water flow rate

\begin{tabular}{lcc}
\hline Operation & $\begin{array}{c}\text { Minimum fresh water } \\
\text { flow rate }\left(\mathrm{m}^{3} / \mathrm{h}\right)\end{array}$ & $\begin{array}{c}\text { Outlet concentration } \\
\left(\mathrm{g} / \mathrm{m}^{3}\right)\end{array}$ \\
\hline 4 & 0.502 & 60 \\
11 & 2.6 & 60 \\
13 & 3 & 50 \\
Overall & 6.102 & 50.6 \\
\hline
\end{tabular}

$f_{11, \min }=\frac{84.4(\mathrm{gr} / \mathrm{h})}{[60-27]\left(\mathrm{g} / \mathrm{m}^{3}\right)}=2.6\left(\mathrm{~m}^{3} / \mathrm{h}\right)$

$f_{13, \min }=\frac{68.4(\mathrm{gr} / \mathrm{h})}{[50-27]\left(\mathrm{g} / \mathrm{m}^{3}\right)}=3\left(\mathrm{~m}^{3} / \mathrm{h}\right)$

Table 8 shows the results above.

Therefore, there are minimum fresh water flow rate equal to $6.102 \mathrm{~m}^{3} / \mathrm{h}$. This is less than total required flow rate, $7.128 \mathrm{~m}^{3} / \mathrm{h}$, hence it is acceptable.

Minimum flow rate of fresh water with reuse

Then, after establishment of the freshwater requirements for the system without water reuse, process integration is to be carried out. Wastewater from one operation can be reused directly in another operation provided that level of contamination from operation A does not interfere with operation B (i.e., the inlet concentration for the water stream remains below $\left(C_{B, i n}^{\mathrm{Lim}}\right.$ ). Reusing the water streams in this way reduces both freshwater and wastewater volumes, but leaves the mass load of contaminant transferred unchanged. In process integration, the concentration composite curve or concentration interval diagram (CID) are applied (Mann and Liu, 1999).

\section{Concentration composite curve}

Fig. 3 shows the concentration composite curve for four operations in Alupan industry. In this curve, the $x$ axis is the mass load and the y-axis is concentration. In this Fig. there is an inverse relationship between the slope of the water supply line and water flow rate as follows:

$$
\text { Slope }=\frac{1}{f_{\min }\left(m^{3} / h\right)}
$$

The point that this line touches the concentration composite curve is the pinch point (Wang and Smith, 1994a). The pinch point for these operations is in the concentration of $50\left(\mathrm{gr} / \mathrm{m}^{3}\right)$. The advantage of determining of this point is that, the operations above it do not need for freshwater and the operations below that need freshwater.

\section{Concentration interval diagram}

The concentration intervals are applied again like the concentration composite curve (Table 9). In this Table, the mass load transferred in each concentration interval is to be calculated. It can be seen that, pinch point is in interval equal to $50\left(\mathrm{gr} / \mathrm{m}^{3}\right)$. For calculation the mass load transferred in each concentration interval, following simple equation is applicable:

$$
\begin{aligned}
& m_{k}(g / h)=\left[C_{k+1}^{*}-C_{k}^{*}\right]\left(g / m^{3}\right) \times \sum_{i} f_{i}^{\text {Lim }}\left(\mathrm{m}^{3} / \mathrm{h}\right) \\
& m_{1}(g / h)=[40-30]\left(g / \mathrm{m}^{3}\right) \times[3.42+2.88] \\
& \left(\mathrm{m}^{3} / \mathrm{h}\right)=63(g / \mathrm{h}) \\
& m_{2}(g / h)=[50-40]\left(g / \mathrm{m}^{3}\right) \times[3.42+2.88+0.828] \\
& \left(m^{3} / \mathrm{h}\right)=71.28(g / h) \\
& m_{2}(g / h)=[60-50]\left(\mathrm{g} / \mathrm{m}^{3}\right) \times[2.88+0.828] \\
& \left(m^{3} / \mathrm{h}\right)=37.08(\mathrm{~g} / \mathrm{h})
\end{aligned}
$$

The flow rate can be calculated from the following equation: 


$$
\begin{aligned}
& f_{k}\left(\mathrm{~m}^{3} / \mathrm{h}\right)=\frac{\Delta m_{k}(g / h)}{C_{k}^{*}\left(g / \mathrm{m}^{3}\right)} \\
& f_{1}\left(\mathrm{~m}^{3} / \mathrm{h}\right)=\frac{0(g / \mathrm{h})}{30\left(g / \mathrm{m}^{3}\right)}=0\left(\mathrm{~m}^{3} / \mathrm{h}\right) \\
& f_{1}\left(\mathrm{~m}^{3} / \mathrm{h}\right)=\frac{63(g / \mathrm{h})}{40\left(\mathrm{~g} / \mathrm{m}^{3}\right)}=1.5\left(\mathrm{~m}^{3} / \mathrm{h}\right) \\
& f_{1}\left(\mathrm{~m}^{3} / \mathrm{h}\right)=\frac{134.28(\mathrm{~g} / \mathrm{h})}{50\left(\mathrm{~g} / \mathrm{m}^{3}\right)}=2.6\left(\mathrm{~m}^{3} / \mathrm{h}\right) \\
& f_{1}\left(\mathrm{~m}^{3} / \mathrm{h}\right)=\frac{171.36(\mathrm{~g} / \mathrm{h})}{60\left(\mathrm{~g} / \mathrm{m}^{3}\right)}=2.9\left(\mathrm{~m}^{3} / \mathrm{h}\right)
\end{aligned}
$$

\section{Water using network design}

For designing preliminary water using network, Mann and Liu's concentration interval method is highly appropriate.

\section{Grid diagram}

Briefly, a gird diagram consists of concentration interval boundaries, process streams, water streams and water using units and their mass loads of contaminant:

- Firstly, horizontal dashed lines are depicted which show the concentration interval boundaries. To the left of the diagram, arrows pointing downward (solid lines) are drawn between the inlet and the outlet concentrations of the contaminant to represent each process stream representing the water using operation.

\begin{tabular}{|c|c|c|c|c|c|c|}
\hline $\begin{array}{l}\text { Concentration } \\
\left(\mathrm{g} / \mathrm{m}^{3}\right)\end{array}$ & $\begin{array}{l}\text { Operation } 13 \\
3.42\left(\mathrm{~m}^{3} / \mathrm{h}\right)\end{array}$ & $\begin{array}{c}\text { Operation } 11 \\
2.88(\mathrm{~m} 3 / \mathrm{h})\end{array}$ & $\begin{array}{l}\text { Operation } 4 \\
0.828\left(\mathrm{~m}^{3} / \mathrm{h}\right)\end{array}$ & $\Delta \mathrm{m}(\mathrm{g} / \mathrm{h})$ & $\begin{array}{c}\text { Cumulative Mass } \\
\text { Load(g/h) }\end{array}$ & Flow rate $\left(\mathrm{m}^{3} / \mathrm{h}\right)$ \\
\hline 30 & & & & & 0 & 0 \\
\hline 40 & & & $\uparrow$ & & 63 & 1.5 \\
\hline & & & & 71.28 & & \\
\hline 60 & & & & & 171.36 & 2.9 \\
\hline
\end{tabular}

- In each interval, the mass load of contaminant to be transferred for each process stream is calculated.

Table 9: Concentration interval diagram

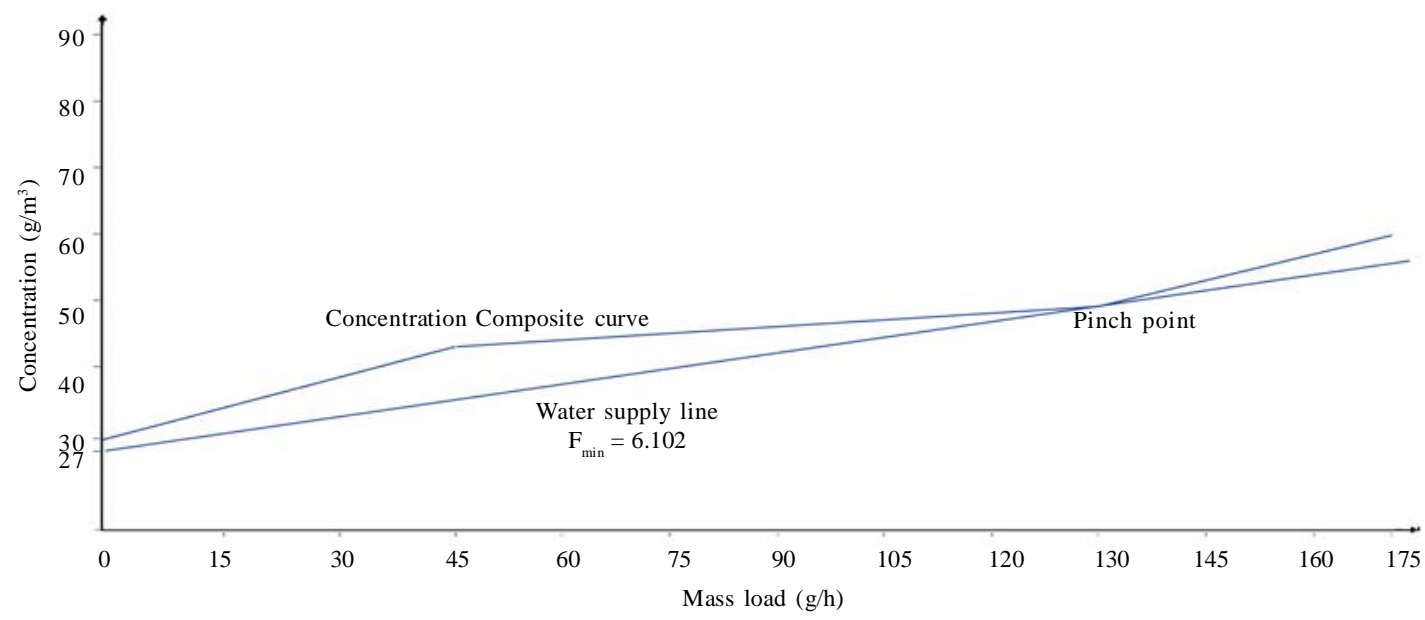

Fig. 2: Concentration composite curve 


$$
\begin{aligned}
& m_{i, k}(g / h)=\Delta m_{i, t o t}(g / h)\left[\frac{C_{k+1}^{*}-C_{k}^{*}}{C_{i, \text { out }}^{L i m}-C_{i, i n}^{L i m}}\right] \\
& m_{13,1}(g / h)=68.4(g / h)\left[\frac{40-30}{50-30}\right]=34.2 \\
& m_{13,1}(g / h)=68.4(g / h)\left[\frac{50-40}{50-30}\right]=34.2 \\
& m_{11,1}(g / h)=84.4(g / h)\left[\frac{40-30}{60-30}\right]=28.14 \\
& m_{11,2}(g / h)=84.4(g / h)\left[\frac{50-40}{60-30}\right]=28.14 \\
& m_{11,3}(g / h)=84.4(g / h)\left[\frac{60-50}{60-30}\right]=28.14 \\
& m_{4,2}(g / h)=16.56(g / h)\left[\frac{50-40}{60-40}\right]=8.28 \\
& m_{4,3}(g / h)=16.56(g / h)\left[\frac{60-50}{60-40}\right]=8.28 \\
&
\end{aligned}
$$

For each operation, in a selected concentration interval, the water flow rate is calculated corresponding to the mass load of the contaminant for operation $i$ in interval $k, f_{i, k}^{\text {tot }}$ :

$f_{i, k}^{\text {tot }}\left(m^{3} / h\right)=\frac{m_{i, k}(g / h)}{\left[C_{k+1}^{*}-C_{i, k}^{w}\right]\left(g / m^{3}\right)}$

In this equation, $C_{i, k}^{w}$ is the average contaminant concentration of the water stream for operation $i$ entering interval $k$.

\section{Interval 1:}

In this interval, it is necessary to use fresh water:

$$
f_{13,1}\left(\mathrm{~m}^{3} / \mathrm{h}\right)=\frac{32.4(\mathrm{~g} / \mathrm{h})}{[40-27]\left(\mathrm{g} / \mathrm{m}^{3}\right)}=2.63\left(\mathrm{~m}^{3} / \mathrm{h}\right)
$$

With drawing the dashed bold arrow, the fresh water needed for operation 13 in interval 1 is shown.

$$
f_{11,1}\left(\mathrm{~m}^{3} / \mathrm{h}\right)=\frac{28.4(g / \mathrm{h})}{\left[40-27\left(g / \mathrm{m}^{3}\right)\right.}=2.16\left(\mathrm{~m}^{3} / \mathrm{h}\right)
$$

The second dashed bold arrow, transfer $2.16\left(\mathrm{~m}^{3} / \mathrm{h}\right)$ freshwater to operation 11 in interval 1.

Interval 2:

In this interval, there are three water using operations. Water sources are selected in the following order:

First, water is reused from the same process in the previous interval; second, water is to be reused from other process and finally, freshwater is achieved.

Firstly, water needed for operation 13 is calculated in second. This operation can use the outlet water from operation 13 in interval 1 . Therefore,

$$
f_{13,2}\left(\mathrm{~m}^{3} / \mathrm{h}\right)=\frac{32.4(\mathrm{~g} / \mathrm{h})}{[50-40]\left(\mathrm{g} / \mathrm{m}^{3}\right)}=3.42\left(\mathrm{~m}^{3} / \mathrm{h}\right)
$$

This operation needs $0.455\left(\mathrm{~m}^{3} / \mathrm{h}\right)$ freshwater to transfer mass load of $28.4(\mathrm{~g} / \mathrm{h})$.

For operation 4 in interval 2, it shall use freshwater.

$$
f_{4,2}\left(\mathrm{~m}^{3} / \mathrm{h}\right)=\frac{8.28(\mathrm{~g} / \mathrm{h})}{[50-27]\left(\mathrm{g} / \mathrm{m}^{3}\right)}=0.36\left(\mathrm{~m}^{3} / \mathrm{h}\right)
$$

\section{Interval 3:}

In this interval, there are two operations (11 and 4). According to the following equation, operation 11 needs $2.814 \mathrm{~m}^{3} / \mathrm{h}$ water for transferring $28.14 \mathrm{~g} / \mathrm{m}^{3}$ mass load of contaminant.

$$
f_{11,3}\left(\mathrm{~m}^{3} / \mathrm{h}\right)=\frac{28.14(\mathrm{~g} / \mathrm{h})}{[60-50]\left(\mathrm{g} / \mathrm{m}^{3}\right)}=2.814\left(\mathrm{~m}^{3} / \mathrm{h}\right)
$$

The outlet of operation 11 in interval 2 is $2.615 \mathrm{~m}^{3} / \mathrm{h}$, then, $0.2 \mathrm{~m}^{3} / \mathrm{h}$ water is transferred from operation 13 in interval 2, to this operation. $2.814-2.615=0.199 \mathrm{H} \sim 0.2$ 
The next operation is operation 4 . The required water for this operation is calculated with the same manner introduced above.

$$
f_{4,3}\left(\mathrm{~m}^{3} / \mathrm{h}\right)=\frac{8.28(\mathrm{~g} / \mathrm{h})}{[60-50]\left(\mathrm{g} / \mathrm{m}^{3}\right)}=0.828\left(\mathrm{~m}^{3} / \mathrm{h}\right)
$$

The outlet of operation 4 in interval 2 is less than this amount. Thus, $0.468 \mathrm{~m}^{3} / \mathrm{h}$ water is transferred from operation 13 in interval 2 to this operation.

\section{$0.36 \mathrm{~m}^{3} / \mathrm{h}+0.468 \mathrm{~m}^{3} / \mathrm{h}=0.828 \mathrm{~m}^{3} / \mathrm{h}$}

Fig. 4 show Grid diagram and Block diagram for three rinsing operations, respectively in Alupan.

\section{CONCLUSION}

Today, the lack of freshwater, damage of discharging wastewater in the environment, costs of freshwater supplying and wastewater treatment, have forced researcher to develop various methods to decreasing freshwater usage, especially in high consumption industry. Water consumptions in anodizing is high and because of high contamination of outlet of anodizing wastewater to the environment and surface and groundwater, producing an applicable method to reduce water consumptions of anodizing and therefore, refusing of wastewater is very important. In the other hand, waste minimization through pinch technology, is an effective method to reach this goal.

In this research, with applying the pinch technology in three rinsing operations, the flow rate reduced up to $1.026 \mathrm{~m}^{3} / \mathrm{h}$ (from $7.128 \mathrm{~m}^{3} / \mathrm{h}$ to $6.102 \mathrm{~m}^{3} / \mathrm{h}$ ). The method of this research is based on single contaminant; however, a complexity of efficient contaminant is used as a standard to be secure to use of outlet of one operation to another.

It is better to use multiple contaminant to have good results. The mathematical optimization and using of computer programming have exact results.

\section{Nomenclature}

Q: The value of a parameter according to standard. $\mathrm{W}$ : The weight of a parameter according to standard. $C_{i, i n}^{\text {Lim }}$ : The limiting contaminant level in inlet of operation.

$C_{i, \text { out }}^{\text {Lim }}$ : The limiting contaminant level in outlet of operation.

$\Delta m_{i, t o t}$ : The mass load of transferred contaminant.

$C_{i, \text { in }}^{w}$ : Concentration of water in inlet of operation.

$f_{\text {min }}$ : Minimum flow rate in inlet of operation.

$m_{i, k}$ : The mass load of transferred contaminant in each interval $\mathrm{k}$ for operation $\mathrm{i}$.

$f_{i, k}$ : The required flow rate for transferring contaminant in each interval $\mathrm{k}$ for operation $\mathrm{i}$.

$C_{k+1}^{*}$ : Contaminant concentration in upper interval boundary.

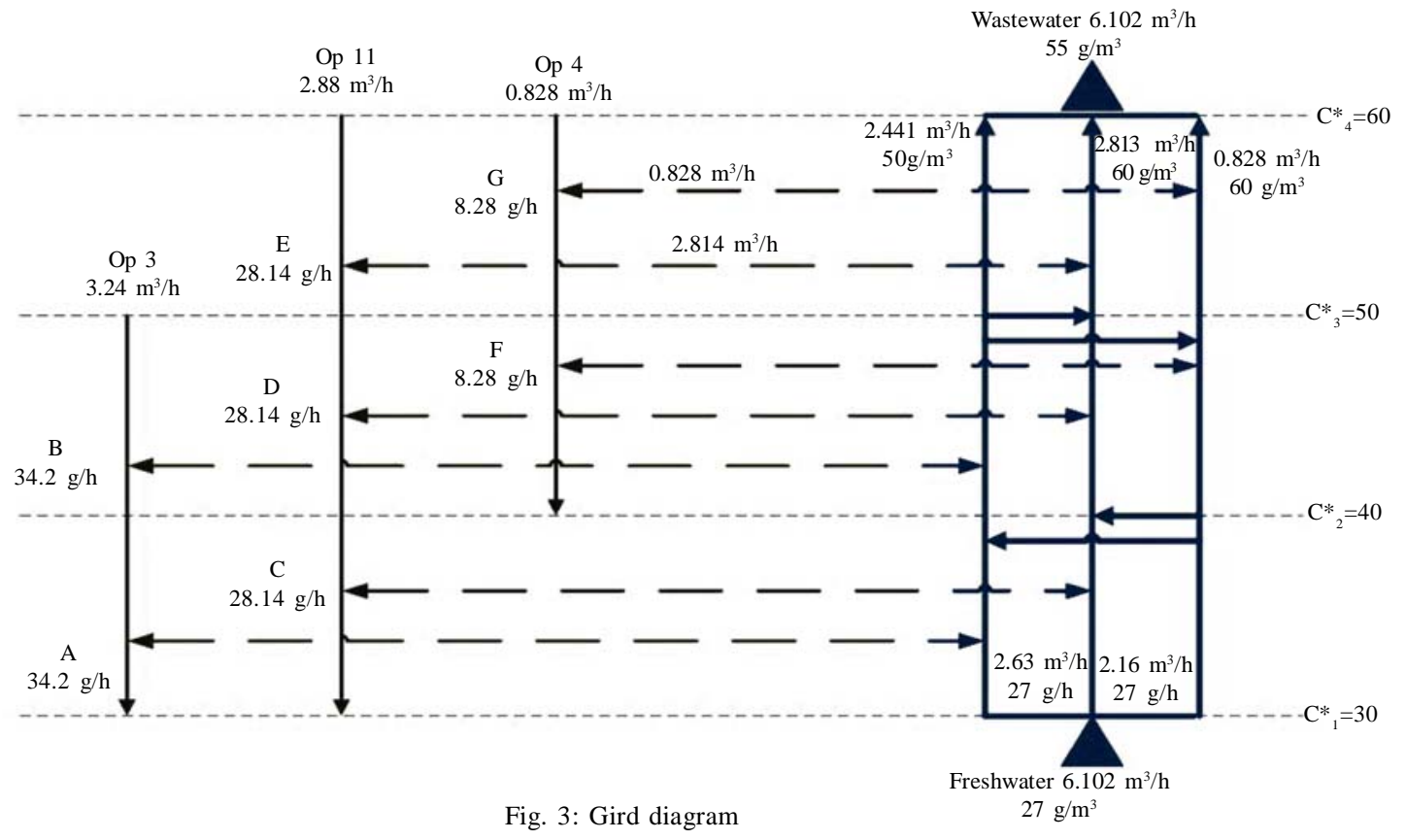




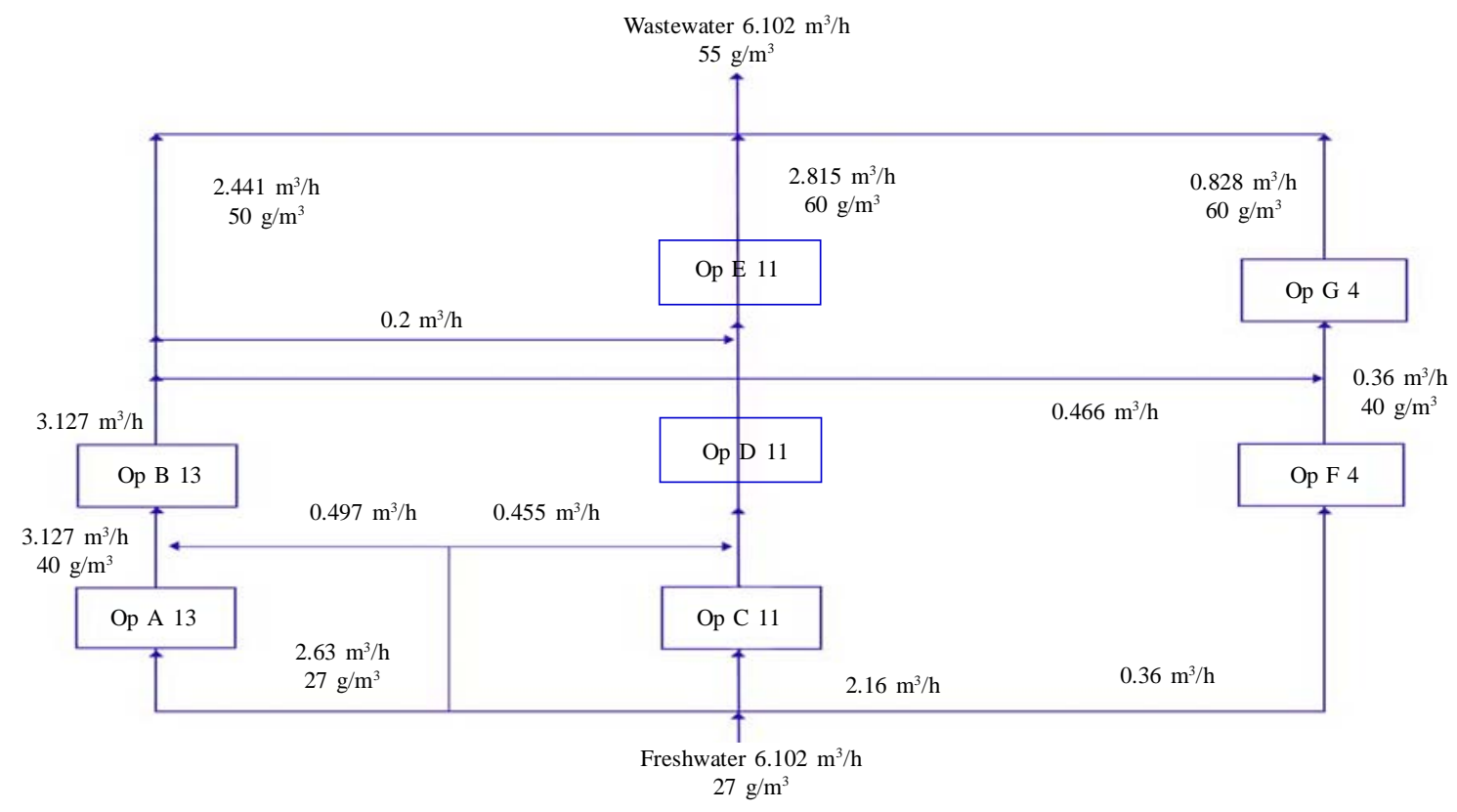

Fig. 4: Block diagram

\section{ACKNOWLEDGMENTS}

The authors grateful to Alopan Company as well as Ms. Soleimani for their cooperation in this research.

\section{REFERENCES}

Abbaspour, M.; Mirbagheri, S. A.; Monavvari, M.; Javid, A. H.; Zarei, H., (2009). Conceptual hydrosalinity model for prediction of salt load from wastewater flows into soil and groundwater. Int. J. Environ. Sci. Tech., 6 (3), 359-368 (10 pages).

Alva- Argaeza, A.; Vallianatos, A.; Kokossis, A., (1999). A multi- contaminant transshipment model for mass exchange networks and wastewater minimization problems. Comput. Chem. Eng., 23 (10), 1439-1453 (15 pages).

Alva-Argaez, A.; Kokossis, A. C.; Robin, S., (2007). The design of water using systems in petroleum refining using a water pinch decomposition. Chem. Eng. J., 128 (1), 33-46 (14 pages).

Carlos, E.; Mariano, R.; Victor, H., (2007). Multi-objective optimization of water-using systems. Eur. J. Oper. Res., 181 (3), 1691-1707 (17 pages).

Castro, P.; Matos, H.; Fernandes, M. C., (1999). Improvements for mass exchange networks design. Chem. Eng. Sci., 54 (11), 1649-1665 (17 pages).

Dhole, V. R.; Ramchandani, N., (1996). Make your process water pay for itself. Chem. Eng., 103 (1), 100-103 (4 pages).

El-Halwagi, M. M.; Manousiouthakis, V., (1989). Synthesis of mass exchange networkers. AIChEJ, 35 (8), 1233-1244 (11 pages).

El-Halwagi, M. M.; Gabriel, F.; Harell, D., (2000). Rigorous graphical targeting for resource conservation via material recycle / reuse networks. Ind. Eng. Chem. Resour., 42 (19), 4319-4328 (10 pages).

Gomes, J. F. S.; Eduardo, M. Q; Fenando, L. P., (2007). Design procedure for water / wastewater minimization: Single contaminant. J. Clea. Produc., 15 (5), 474-485 (12 pages).

Hallale, N., (2002). A new graphical targeting method for water minimization. Adv. Environ. Res., 6 (3), 377-390 (14 pages).

Igbinosa, E. O.; Okoh, A. I., (2009). Impact of discharge wastewater effluents on the physico-chemical qualities of a receiving watershed in a typical rural community. Int. J. Environ. Sci. Tech., 6 (2), 175-182 (8 pages).

Jezowski, J., (2008). Review and analysis off approaches for designing optimum industrial water networks. Chem. Process Eng., 29, 663-681 (19 pages).

Juliana, F. S.; Eduardo, M. Q.; Fernando, L. P. P., (2007). Design procedure for water/wastewater minimization: Single contaminant. J. Clea. Product., 15 (5), 474-485 (12 pages).

Kutepove, A. M.; Meshalkin, V. P.; Nevskii, A. V., (2002). Modified water pinch method for desining resource efficient chemical engineering systems. Doklady Chem., 383 (46)123-127 (5 pages).

Kai, C.; Xiao F.; Hang M., (2007). Pinch multi -agent genetic algorithm for optimizing water using networks. Comput. Chem. Eng., 31 (12), 1565-1575 (11 pages).

Linnhof, B.; Hindmarsh, E., (1970). The pich designing method for heat exchanger networks. Chem. Eng. Sci., 38 (5), 745-763 (19 pages).

Manan, Z. A.; Wan Alwi, S. R.; Vjanag. Z., (2006). Water pinch analysis for an urbun system: A case study on the sultan Islmail Mosque at the Univercity Technology 
Malaysia (UTM). Desalination, 194 (1-3), 52-68 (17 pages).

Mann, J.; Liu, A.Y., (1999). Industrial water reuse and wastwater minimization. McGraw-Hill Publication.

Mubarak Ebrahm, A. K., (2000). Pinch technology: An efficient tool for chemical-plant engineering and capital-cast saving. Appl. Energ., 65 (1-4), 45-49 (5 pages).

Panjeshahi, M. H.; Ataei, A., (2008). Application of an environmentally optimum cooling water system design in water and energy conservation. Int. J. Environ. Sci. Tech., 5 (2), 251-262 (12 pages).

Rabie, A. H.; El-Halwagi, M. M., (2008). Synthesis and sscheduling of optimal batch water networks. Chinese J. Chem. Eng., 16 (3), 474-479 (5 pages).

Sorin, M.; Bedard, S., (1999). The global pinch point in water reuse networks. Institution of Chemical Engineers. Trans. IChemE. Part B., 77, 305-308 (4 pages).

Schneider, Z.; Brouckart, C. J.; Buckley, C. A., (2000). Using water pinch analysis to reduce effluent in the production of L-Lysine. WISA Biennial Conference, Sun City, South Africa.

Song, L.; Shaobing, C. A. I.; Pingjing. Y. A. O., ( 2006). A new method for designing water network based on variable removal ration treatment process, $16^{\text {th. }}$ European Symposium on Computer Aided Process Engineering and $19^{\text {th. }}$ International Symposium on Process Systems Engineering,Published by Elsevier B.V.

Soon, K. H.; Ho-Kyung, L.; In-Beum, L., (2002). Modified approach of wastewater minimization in multiole contaminant system. Theor. Ap. Chem. Eng., 8 (2), 30813084 (4 pages).

Shaobo, H.; Hefei, Z., (2008). A hybrid solar desalination process of the multi-effect humidification dehumidification and basin- type unit. Desalination, 220 (1-3), 552-557 (6 pages).

Shoaib, A. M., Said, M. A., Moustafa, E. A., (2008). A hierarchical approach for the synthesis of batch water networks. Comput. Chem. Eng., 32 (3), 530-539 (10 pages).

Thaokozani, M., (2005). Wastewater minimisation using central reusable water storage in batch plant. Comput. Chem. Eng. 29 (7), 1631-1646 (16 pages).

Vander Bruggen, B.; Braeken, L., (2006). The challeng of zero discharge from water balance to regeneration. Desalination, 188 (1-3), 177-183 (7 pages).

Wang, Y. P.; Smith, R., (1994). Wastewater minimization. Chem. Eng. Sci., 49, 981-1006 (26 pages).

Wan Alwi, S. R.; Manan, Z. A., (2008). A holistic framework for design of cost effective minimum water utilization network, J. Environ. Manage., 88 (2), 219-259 (41 pages).

Yu-Der, L.; Jun-Hong, C.; Jian- Kai, C.; Hsiao-Ping, H.; ChengChing, Y., (2008). Process alternative for methyl acetate conversion using reactive distillation. Hydrolysis. Chem. Eng. Sci., 63 (6), 1668-1682 (15 pages).

Zhaolin, G.; Zhonghua, T.; Nan, X. Y. L., (2007). Retrofitting of a distillery based on process synthesis. Energ. Convers. Manage., 48 (2), 3335-3343 (8 pages).

\section{AUTHOR (S) BIOSKETCHES}

Khezri, S. M., Ph.D., Assistant Professor, Department of the Environmental Engineering, Graduate School of the Environment and Energy, Science and Research Branch, Islamic Azad University, Tehran, Iran.

Email: khezri_m@yahoo.com

Lotfi, F., M.Sc., Department of the Environmental Engineering, Graduate School of the Environment and Energy, Science and Research Branch, Islamic Azad University, Tehran, Iran. Email: fatemeh.lotfi@gmail.com

Tabibian, S., M.Sc, Faculty of Agriculture, Roodehen Branch, Payame Noor University, Tehran, Iran. Email: tsahart@yahoo.com

Erfani, Z., M.Sc., Department of the Environmental Engineering, Graduate School of the Environment and Energy, Science and

Research Branch, Islamic Azad University, Tehran, Iran. Email: helia.erf2000@yahoo.com

How to cite this article: (Harvard style)

Khezri, S. M.; Lotfi, F.; Tabibian, S.; Erfani, Z., (2010). Application of water pinch technology for water and wastewater minimization in aluminum anodizing industries. Int. J. Environ. Sci. Tech., 7 (2), 281-290. 